\title{
PENGARUH CAR, NPF, FDR, DAN OER TERHADAP ROA PADA BANK PEMBIAYAAN RAKYAT SYARIAH DI INDONESIA PERIODE JANUARI 2009 HINGGA MEI 20141)
}

\author{
Linda Widyaningrum \\ Mahasiswa Program Studi S1 Ekonomi Islam-Fakultas Ekonomi dan Bisnis-Universitas Airlangga \\ Email:ntungvale@gmail.com \\ Dina Fitrisia Septiarini \\ Departemen Ekonomi Syariah-Fakultas Ekonomi dan Bisnis-Universitas Airlangga \\ Email: dina.fitrisia@gmail.com
}

\begin{abstract}
:
Islamic Rural Bank is intermediary institution that collect and distribute the fund in financing. BPRS management hope that every operational activities always shows good performance in order to obtain optimal benefit. One of the way to measure performance is calculating financial ratios. The purpose of this research to know the effect of CAR, NPF, FDR, and OER on ROA in industry of Islamic Rural Bank period January 2009 until May 2014 in partial and simultaneous. This research method used quantitative approach. Sample of this research was based on monthly period, so there were 65 months/samples. Sampling technique used purposive sampling. All data taken from Sharia Islamic Statistic. Analyze technique used multiple regression.

The results of this research showed that in simultaneous, CAR, NPF, FDR, and OER had significant effect on ROA. In partial, CAR, NPF, and FDR had not significant effect on ROA, beside OER had significant effect on ROA.
\end{abstract}

Keywords: CAR, NPF, FDR, OER, ROA

\section{PENDAHULUAN}

\section{Latar Belakang}

Syariah terbagi dua macam yaitu ibadah dan muamalah (Ismail, 2011:11). Ibadah dilakukan sebagai sarana dalam mendekatkan diri kepada Allah SWT, sedangkan muamalah ditujukan untuk bagaimana seharusnya manusia berkomunikasi atau berhubungan satu sama lain dalam berbagai aspek/bentuk sesuai dengan yang telah Allah SWT tetapkan. Salah satu bentuk muamalah tersebut adalah kegiatan ekonomi yang seluruh kegiatannya harus dilandaskan pada prinsip-prinsip ekonomi Islam.

Bank Pembiayaan Rakyat Syariah (BPRS) adalah salah satu bentuk perbankan syariah yang berperan sebagai lembaga intermediasi yang setiap kegiatannya berlandaskan pada prinsip-prinsip syariah. BPRS lebih mengutamakan untuk memberikan pembiayaan kepada usaha mikro, kecil, dan menengah, serta BPRS beroperasi pada daerah pedesaan/kabupaten dimana pada daerah tersebut masih banyak masyarakat yang membutuhkan pembiayaan. Sehingga dapat dikatakan bahwa BPRS dapat memberikan pelayanan dengan jangkauan yang lebih luas kepada masyarakat (Outlook Perbankan Syariah Tahun 2013, 2012:5).

Bank Pembiayaan Rakyat Syariah adalah bank yang beroperasi secara 1 Jurnal ini merupakan bagian dari skripsi Linda Widyaningrum, nim. 041114038 , yang diuji pada tanggal 27 April 2015 
profit oriented, sehingga dalam kegiatan operasionalnya tetap mencari keuntungan. Salah satu rasio yang digunakan untuk mengukur keuntungan adalah rasio Return on Assets (ROA). Hutagalung dkk (2013) menyatakan bahwa semakin besar ROA menunjukkan kinerja keuangan yang semakin baik, karena tingkat pengembalian (return) semakin besar. Setiap Muslim diperbolehkan untuk mencari keuntungan sebab keuntungan adalah pendapatan yang berguna untuk kelangsungan hidup. Hal ini sesuai dengan firman Allah SWT dalam Surat Al-Baqarah ayat 198:

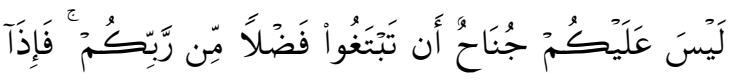
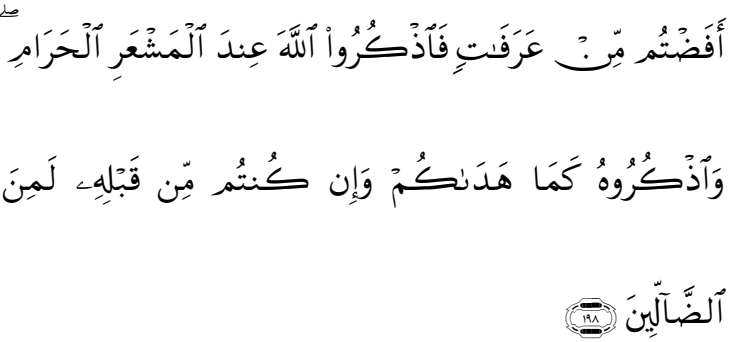

Laisa 'alaikum junāḥun an tabłagū faḍlam mir rabbikum, fa iżā afaḍtum min 'Arafōtin fażkurullāha 'indal-Masy'aril-Haram, ważkurūhu kamā hadākum, wa in kuntum min qablihī laminaḍ-ḍ̄allın.

"Tidak ada dosa bagimu untuk mencari karunia (rezeki hasil perniagaan) dari Tuhanmu. Maka apabila kamu telah bertolak dari 'Arafah, berzikirlah (dengan menyebut) Allah sebagaimana yang ditunjukkan-Nya kepadamu; dan sesungguhnya kamu sebelum itu benarbenar termasuk orang yang sesat." (Departemen Agama RI, Mushaf AlQur'an dan Terjemahnya Revisi Tahun 2004)

Terdapat beberapa rasio kevangan yang mempengaruhi ROA, yaitu Capital Adequacy Ratio (CAR), Non Performing Financing (NPF), Financing to Deposit Ratio (FDR), dan Operational Efficiency Ratio (OER). Rasio kecukupan modal atau Capital Adequacy Ratio (CAR) untuk mengetahui kemampuan modal yang dimiliki dalam menyerap atau menanggung kerugian BPRS. Apabila bank memiliki modal yang cukup dalam menyerap kerugian, maka semakin besar kemungkinan bank dalam menghasilkan keuntungan.

Rasio Non Ferforming Financing (NPF) diukur dengan membandingkan jumlah pembiayaan bermasalah dengan total pembiayaan. Nilai NPF dapat bertambah apabila jumlah pembiayaan bermasalah meningkat. Apabila rasio NPF meningkat maka pembiayaan bermasalah yang ditanggung BPRS bertambah dan mengakibatkan kerugian yang dihadapi meningkat sehingga dapat menurunkan tingkat keuntungan BPRS.

Rasio Financing to Deposit Ratio (FDR) diukur dengan membandingkan total pembiayaan dengan total Dana Pihak Ketiga (DPK). FDR dalam perbankan konvensional lebih dikenal dengan istilah Loan to Deposit Ratio (LDR). Sukarno dan Syaichu (2006) menyatakan semakin tinggi LDR maka laba perusahaan mempunyai kemungkinan untuk meningkat dengan 
catatan bank tersebut mampu menyalurkan kreditnya dengan optimal. Hal ini juga berlaku pada FDR, kenaikan pada rasio FDR menandakan bahwa adanya peningkatan dalam penyaluran pembiayaan kepada masyarakat, sehingga apabila rasio ini naik maka keuntungan bank juga naik dengan asumsi bahwa bank menyalurkan pembiayaannya dengan optimal.

Operational Efficiency Ratio (OER) atau Biaya Operasional terhadap Pendapatan Operasional (BOPO). BOPO digunakan untuk mengukur kemampuan manajemen bank dalam mengendalikan biaya operasional terhadap pendapatan operasional dan semakin kecil rasio ini semakin efisien biaya operasional yang dikeluarkan bank sehingga kemungkinan bank yang bersangkutan dalam kondisi bermasalah juga semakin kecil (Almilia dan Herdiningtyas, 2005). Hal ini berarti semakin kecil kemungkinan bank dalam keadaan bermasalah maka memungkinkan bank untuk meningkatkan keuntungan. Pada kenyataannya, tidak semua teori yang dijelaskan sebelumnya terjadi dalam keadaan riil. Berdasarkan Statistik Perbankan Syariah pada bulan Mei 2014, misalnya pada rasio CAR tahun 2010 mengalami penurunan sebesar 2,52\% dari tahun 2009, sehingga CAR tahun 2010 sebesar $27,46 \%$ dan ROA juga mengalami penurunan sebesar $1,51 \%$ sehingga ROA pada tahun 2010 sebesar 3,49\%. Hal ini berbeda dengan yang terjadi pada tahun 2013. Pada tahun 2013 CAR mengalami penurunan sebesar $3,08 \%$ dari tahun 2012, sehingga nilai CAR tahun 2013 sebesar $22,08 \%$ yang semula pada tahun 2012 sebesar $25,16 \% \%$, namun ROA justru mengalami peningkatan sebesar $0,25 \%$ dari 2,64\% pada tahun 2012 menjadi 2,89\% pada tahun 2013. Padahal penurunan CAR seharusnya menyebabkan ROA menurun.

Terdapat beberapa penelitian yang memberikan hasil yang berbedabeda. Penelitian yang dilakukan oleh Widati (2012) yang berjudul "Analisis pengaruh CAMEL terhadap Terhadap Kinerja Perusahaan Perbankan yang Go Public" menyatakan bahwa CAR berpengaruh positif signifikan terhadap ROA, sedangkan penelitian yang dilakukan Pratiwi (2012) yang berjudul "Pengaruh CAR, BOPO, NPF, dan FDR Terhadap Return On Assets (ROA) Bank Umum Syariah (Studi Kasus pada Bank Umum Syariah di Indonesia Tahun 20052010)" menyatakan bahwa CAR berpengaruh negatif dan tidak signifikan terhadap ROA.

Adanya bukti empiris yang menunjukkan masing-masing variabel mengalami fluktuasi setiap tahunnya, adanya ketidakkonsistenan data terhadap teori yang dikemukakan, serta adanya hasil penelitian terdahulu yang menunjukkan perbedaan, maka peneliti tertarik untuk melakukan penelitian lebih lanjut dengan memilih subyek penelitian Bank Pembiayaan Rakyat Syariah (BPRS).

\section{Rumusan Masalah}

1. Apakah Capital Adequacy Ratio (CAR), Non Performing Financing 
(NPF), Financing to Deposit Ratio (FDR), dan Operational Efficiency Ratio (OER) berpengaruh secara simultan terhadap Return on Assets (ROA) pada BPRS di Indonesia?

2. Apakah Capital Adequacy Ratio (CAR) berpengaruh terhadap Return on Assets (ROA) pada BPRS di Indonesia?

3. Apakah Non Performing Financing (NPF) berpengaruh terhadap Return on Assets (ROA) pada BPRS di Indonesia?

4. Apakah Financing to Deposit Ratio (FDR) berpengaruh terhadap Return on Assets (ROA) pada BPRS di Indonesia?

5. Apakah Operational Efficiency Ratio (OER) berpengaruh terhadap Return on Assets (ROA) pada BPRS di Indonesia?

\section{Tujuan Penelitian}

1. Untuk mengetahui pengaruh Capital Adequacy Ratio (CAR), Non Performing Financing (NPF), Financing to Deposit Ratio (FDR), dan Operational Efficiency Ratio (OER) secara simultan terhadap Return on Assets (ROA) pada BPRS di Indonesia.

2. Untuk mengetahui pengaruh Capital Adequacy Ratio (CAR) terhadap Return on Assets (ROA) pada BPRS di Indonesia.

3. Untuk mengetahui pengaruh Non Performing Financing (NPF) terhadap Return on Assets (ROA) pada BPRS di Indonesia.
4. Untuk mengetahui pengaruh Financing to Deposit Ratio (FDR) terhadap Return on Assets (ROA) pada BPRS di Indonesia.

5. Untuk mengetahui pengaruh Operational Efficiency Ratio (OER) terhadap Return on Assets (ROA) pada BPRS di Indonesia.

\section{LANDASAN TEORI DAN} PENGEMBANGAN HIPOTESIS

Berdasarkan Undang-Undang Nomor 21 Tahun 2008 tentang Perbankan Syariah, pengertian Bank Pembiayaan Rakyat Syariah (BPRS) adalah bank syariah yang dalam kegiatannya tidak memberikan jasa dalam lalu lintas pembayaran. Oleh karena itu BPRS tidak diperbolehkan menawarkan giro wadiah dan hal inilah yang membedakan BPRS dengan bank umum syariah dan unit usaha syariah (Ismail, $2011: 55$ ).

\section{Kinerja Kevangan Bank Pembiayaan Rakyat Syariah}

Kinerja adalah melakukan pekerjaan dan hasil yang dicapai dari pekerjaan tersebut (Wibowo, 2011:7). Melakukan pengukuran terhadap kinerja keuangan BPRS sangat diperlukan, sebab dari kegiatan tersebut pihak manajemen BPRS dapat menilai apakah perusahaan telah beroperasi secara efektif dan efisien baik dari segi penghimpunan dana maupun segi penyaluran dana. Untuk mengukur kinerja keuangan BPRS, pihak manajemen BPRS dapat melakukan analisis terhadap laporan keuangan BPRS. Analisis terhadap laporan kevangan dapat dilakukan dengan berbagai cara, 
salah satunya adalah analisis rasio keuangan. Gitman dan Zutter (2012:67) menjelaskan bahwa analisis rasio meliputi metode-metode dalam menghitung dan menginterpretasikan rasio-rasio keuangan untuk menganalisis dan memantau kinerja perusahaan.

1. Capital Adequacy Ratio (CAR)

Hutagalung, dkk

menjelaskan CAR adalah rasio keuangan yang berkaitan dengan permodalan perbankan di mana besarnya modal suatu bank akan berpengaruh pada mampu atau tidaknya suatu bank secara efisien menjalankan kegiatannya. CAR merupakan indikator terhadap kemampuan bank untuk menutupi penurunan aktivanya sebagai akibat dari kerugian-kerugian bank yang disebabkan oleh aktiva yang berisiko (Dendawijaya, 2003:123).

\section{Non Performing Financing (NPF)}

Berdasarkan Surat Edaran Bank Indonesia Nomor 9/29/DPbs tanggal 7 Desember 2007, Non Performing Financing (NPF) dihitung dengan membandingkan jumlah pembiayaan bermasalah dengan total pembiayaan yang dimiliki oleh bank. Menurut Bank Indonesia pembiayaan bermasalah dapat dikategorikan ke dalam tiga kategori, yakni kurang lancar, diragukan, dan macet.

3. Financing to Deposit Ratio (FDR)

Financing to Deposit Ratio (FDR) adalah perbandingan antara pembiayaan yang diberikan oleh bank dengan dana pihak ketiga yang berhasil dikerahkan oleh bank (Rivai dan Arifin,
2010:784). Rasio FDR dalam perbankan konvensional dikenal dengan sebutan Loan to Deposit Ratio (LDR). Hutagalung, dkk (2013) menjelaskan semakin tinggi LDR maka laba bank semakin meningkat (dengan asumsi bank tersebut mampu menyalurkan kreditnya dengan efektif), dengan meningkatnya laba bank, maka kinerja bank juga meningkat. Dalam perbankan syariah, rasio FDR dapat digunakan untuk mengukur tingkat efektivitas pembiayaan yang disalurkan, sehingga apabila rasio FDR meningkat maka laba bank juga akan meningkat dengan asumsi bahwa bank dapat menyalurkan pembiayaan secara efektif.

4. Operational Efficiency Ratio (OER)

Operational Efficiency Ratio (OER) atau rasio Biaya Operasional Pendapatan Operasional (BOPO). BOPO digunakan untuk mengukur tingkat efisiensi dan kemampuan bank dalam melakukan kegiatan operasinya (Dendawijaya, 2003:121).

5. Return on Assets (ROA)

Return on Assets (ROA) digunakan untuk mengukur kemampuan manajemen bank dalam memperoleh laba secara keseluruhan (Dendawijaya, 2003:120). Semakin besar ROA suatu bank, semakin besar pula tingkat keuntungan yang dicapai bank tersebut dan semakin baik pula posisi bank tersebut dari segi penggunaan aset (Dendawijaya, 2003:120). Dalam kemampuan bank untuk memperoleh keuntungan juga dipengaruhi oleh beberapa faktor, yakni inflasi, Net Operating Margin (NOM), Liquid 
Assets to Total Assets (LTA), dan Penyisihan Penghapusan Aktiva Produktif (PPAP).

\section{Hubungan Antar Variabel}

Adapun hubungan antar variabel dapat dijelaskan sebagai berikut:

1. Pengaruh CAR Terhadap ROA Johnson dan Johnson (1985) dalam Arifin (2009:159) menyatakan bahwa modal memiliki tiga fungsi dan salah satu fungsi modal sebagai penyangga untuk menyerap kerugian operasional dan kerugian lainnya. Terserapnya kerugian-kerugian bank, maka dapat dikatakan kesempatan bank untuk memperoleh keuntungan juga akan bertambah, sehingga apabila modal bertambah maka keuntungan yang diperoleh bank juga meningkat. Arifin (2009:162) menyatakan bahwa CAR adalah rasio yang digunakan untuk mengetahui tingkat kecukupan modal, sehingga peningkatan pada CAR menyebabkan peningkatan pada ROA.

2. Pengaruh NPF Terhadap ROA Muhammad

(2004:127) menjelaskan bahwa kegiatan penanaman dana dapat menimbulkan risiko kerugian. Risiko kerugian ini dapat berasal dari adanya pembiayaan bermasalah yang dihadapi bank. Non Performing Financing (NPF) merupakan rasio yang digunakan untuk mengetahui berapa besar pembiayaan yang dihadapi bank. Purbaningsih (2014) menyatakan NPF yang semakin besar akan menyebabkan pendapatan yang diterima bank semakin berkurang, sehingga apabila pendapatan yang diterima semakin berkurang maka akan menurunkan profitabilitas (ROA).

3. Pengaruh FDR Terhadap ROA

Salah satu fungsi perusahaan perbankan sebagai lembaga intermediasi adalah menyalurkan pembiayaan kepada nasabah/masyarakat yang membutuhkan dana tambahan untuk melakukan ekspansi usaha. Untuk mengetahui berapa besar pembiayaan yang disalurkan dengan memanfaatkan dana yang dihimpun dapat menggunakan rasio FDR. FDR dalam bank konvensional lebih dikenal dengan sebutan LDR. Sukarno dan Syaichu (2006) menjelaskan bahwa semakin tinggi LDR laba perusahaan mempunyai kemungkinan untuk meningkat dengan catatan bahwa bank tersebut mampu menyalurkan kreditnya secara optimal, maka disimpulkan bahwa LDR berpengaruh positif terhadap laba. Sama halnya pada FDR, apabila FDR naik maka laba yang diperoleh bank juga naik dengan asumsi bahwa bank mampu menyalurkan pembiayaan secara optimal.

4. Pengaruh OER terhadap ROA

OER atau BOPO adalah rasio yang digunakan untuk mengukur efisiensi operasional bank. Sukarno dan Syaichu (2006) menyatakan semakin kecil rasio BOPO, berarti semakin efisien biaya operasional yang dikeluarkan bank yang bersangkutan sehingga kemungkinan besar bagi bank untuk mendapatkan keuntungan yang lebih dan menunjukkan 
bank tidak berada dalam kondisi bermasalah.

\section{Hipotesis}

Hipotesis dalam penelitian ini adalah sebagai berikut:

Hipotesis 1: Capital Adequacy Ratio (CAR), Non Performing Financing (NPF), Financing to Deposit Ratio (FDR), dan Operational Efficiency Ratio (OER) berpengaruh signifikan terhadap Return on Assets (ROA)

Hipotesis 2: Capital Adequacy Ratio (CAR) berpengaruh signifikan terhadap Return on Assets (ROA)

Hipotesis 3: Non Performing Financing (NPF) berpengaruh signifikan terhadap Return on Assets (ROA)

Hipotesis 4: Financing to Deposit Ratio (FDR) berpengaruh signifikan terhadap Return on Assets (ROA)

Hipotesis 5: Operational Efficiency Ratio (OER) berpengaruh signifikan terhadap Return on Assets (ROA)

\section{Model Analisis}

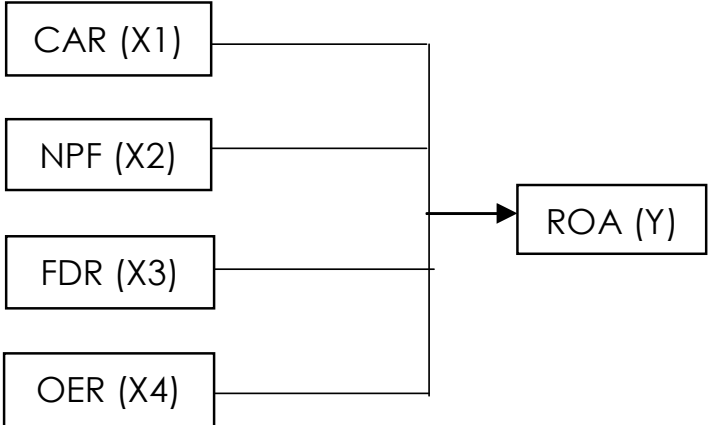

Sumber: Penulis

Gambar 1.

Pengaruh Parsial dan Simultan

III. METODE PENELITIAN

Pendekatan Penelitian

Pendekatan penelitian yang digunakan dalam penelitian ini adalah pendekatan penelitian kuantitatif. Penelitian kuantitatif merupakan penelitian terstruktur dan mengkuantifikasikan data untuk dapat digeneralisasi (Anshori dan Iswati, 2009:13). Identifikasi Variabel

Variabel independen dalam penelitian ini adalah Capital Adequacy Ratio (CAR), Non Performing Financing (NPF), Financing to Deposit Ratio (FDR), dan Operational Efficiency Ratio (OER), sedangkan variabel dependen yang digunakan adalah Return on Assets (ROA).

\section{Definisi Operasional}

Adapun definisi operasional dalam penelitian ini adalah:

1. Capital Adequacy Ratio (CAR)

CAR merupakan rasio yang digunakan untuk menghitung kecukupan modal suatu bank. Berdasarkan peraturan yang telah ditetapkan Bank Indonesia dalam Surat Edaran Bank Indonesia Nomor 9/29/DPbs tanggal 7 Desember 2007, CAR dihitung dengan menggunakan rumus:

$$
\begin{aligned}
& \text { CAR }=\frac{\text { Modal Inti+Relengkag }}{\text { ATMR }} \times 100 \% \ldots . . . . . . .(3.1) \\
& \text { CAR merupakan variabel } \\
& \text { independen pertama dan nilai CAR } \\
& \text { diperoleh dari Statistik Perbankan }
\end{aligned}
$$


Syariah bulanan mulai Januari 2009 hingga Mei 2014 dan skala pengukuran dalam nilai CAR menggunakan skala rasio.

2. Non Performing Financing (NPF)

NPF adalah rasio yang digunakan untuk mengetahui pembiayaan bermasalah yang ditanggung oleh bank berdasarkan dari total pembiayaan yang disalurkan. Berdasarkan Surat Edaran Bank Indonesia Nomor 9/29/DPbs tanggal 7 Desember 2007, NPF dapat dihitung dengan menggunakan rumus:

NPF $=\frac{\text { Jumlah Pembiayan Eermasalah }}{\text { Jumlah Rembiayan }} \mathrm{X}$ $100 \%$

NPF merupakan variabel independen kedua dan nilai NPF diperoleh dari Statistik Perbankan Syariah bulanan mulai Januari 2009 hingga Mei 2014 dan skala pengukuran dalam nilai NPF menggunakan skala rasio.

3. Financing to Deposit Ratio (FDR)

FDR adalah rasio digunakan untuk mengetahui berapa besar pembiayaan yang disalurkan dengan menggunakan Dana Pihak Ketiga (DPK) yang dihimpun oleh BPRS. Suryani (2011) menyatakan bahwa FDR dapat dihitung dengan menggunakan rumus: FDR $=\frac{\text { Jumlah Danayang Diberikan }}{\text { Total Dana Pihakketiga }} \times 100 \% \ldots$ (3.3) independen ketiga dan nilai FDR diperoleh dari Statistik Perbankan Syariah bulanan mulai Januari 2009 hingga Mei 2014 dan skala pengukuran dalam nilai FDR menggunakan skala rasio.

4. Operational Efficiency Ratio (OER)

OER adalah rasio yang digunakan untuk mengetahui efisiensi pihak manajemen bank dalam kegiatan operasionalnya. OER sering disebut dengan BOPO (Biaya Operasional Pembiayaan Operasional) atau OER dapat pula disebut dengan Rasio Efisiensi Operasional (REO). Walaupun terdapat perbedaan dalam istilah penyebutannya, namun rumus yang digunakan dalam penghitungannya sama. Berdasarkan Surat Edaran Bank Indonesia Nomor 9/29/DPbs tanggal 7 Desember 2007, REO dapat dirumuskan sebagai berikut:

$\mathrm{REO}=\frac{\mathrm{BO}}{\mathrm{BO}} \times 100 \%$

OER merupakan variabel independen keempat dan nilai OER diperoleh dari Statistik Perbankan Syariah bulanan mulai Januari 2009 hingga Mei 2014 dan skala pengukuran dalam nilai OER menggunakan skala rasio.

5. Return on Assets (ROA)

ROA adalah rasio yang digunakan untuk mengetahui kemampuan manajemen bank dalam memperoleh laba. Berdasarkan peraturan Bank Indonesia dalam Surat Edaran Bank Indonesia Nomor 9/29/DPbs tanggal 7 Desember 2007, ROA dirumuskan sebagai berikut:

$\mathrm{ROA}=\frac{\text { Laba stbelum } \mathrm{P}_{a j a k}}{\text { Bata-rata total ast }} \times 100 \%$ 
ROA merupakan variabel dependen dan nilai ROA diperoleh dari Statistik Perbankan Syariah bulanan mulai Januari 2009 hingga Mei 2014 dan skala pengukuran dalam nilai ROA menggunakan skala rasio.

\section{Jenis dan Sumber Data}

Seluruh data yang diperoleh dalam penelitian ini merupakan data sekunder yang diperoleh situs resmi Otoritas Jasa Keuangan (OJK) yakni www.ojk.go.id. Data yang digunakan berupa data time series (runtutan waktu) bulanan mulai Januari 2009 hingga Mei 2014 dengan skala industri.

\section{Populasi dan Sampel}

Populasi yang dipakai dalam penelitian ini adalah seluruh Bank Pembiayaan Rakyat Syariah di Indonesia yang periode pelaporan bulanan pertama kali dipublikasikan ke dalam situs resmi OJK dalam bentuk Statistik Perbankan Syariah mulai Juni 2003 hingga Mei 2014, yakni sebanyak 129 periode/bulan.

Penelitian ini dimulai pada Januari 2009 hingga Mei 2014, sehingga terdapat 65 periode penelitian. Teknik penentuan sampel yang digunakan dalam penelitian ini adalah teknik sampling purposive. Teknik sampling purposive adalah teknik penentuan sampel dengan pertimbangan tertentu (Anshori dan Iswati, 2009:105). Adapun pertimbangan yang diambil dari penelitian ini adalah berdasarkan pada kelengkapan data bulanan dari variabel-variabel penelitian yang tersaji dalam Statistik Perbankan
Syariah (SPS) yang dipublikasikan dalam situs resmi OJK.

\section{Teknik Analisis}

Teknik analisis dalam penelitian ini menggunakan teknik analisis regresi linier berganda. Langkah pertama dalam teknik analisis regresi linier berganda sebelum persamaan model regresi terbentuk adalah melakukan uji asumsi klasik yakni uji normalitas, uji autokorelasi, uji multikolinieritas, uji heteroskedisitas, dan uji linieritas. Setelah seluruh uji asumsi klasik terpenuhi, maka langkah selanjutnya adalah menentukan koefisien determinasi $\left(R^{2}\right)$ dan uji hipotesis yakni uji $F$ dan uji t. Uji $F$ digunakan untuk menguji pengaruh simultan variabel independen terhadap variabel dependen, sedangkan uji † digunakan untuk menguji pengaruh secara parsial variabel independen terhadap variabel dependen. Seluruh data diolah dengan menggunakan bantuan piranti lunak (software) PASW Statistics versi 18.

\section{HASIL DAN PEMBAHASAN}

\section{Deskripsi Hasil Penelitian}

1. Deskripsi CAR

Variabel CAR mencapai nilai terendah pada bulan September 2013 yakni sebesar $21,96 \%$, sedangkan variabel CAR mencapai nilai tertinggi pada bulan Oktober 2009 yakni sebesar 43,86\%. Ratarata variabel CAR mulai bulan Januari 2009 hingga Mei 2014 sebesar 26,88\%.

2. Deskripsi NPF

Variabel NPF mencapai nilai terendah sebesar $6,11 \%$ pada bulan Desember 2011 dan mencapai nilai 
tertinggi pada bulan Januari 2009 sebesar $8,81 \%$. Selama periode pengamatan, ratarata nilai variabel NPF sebesar 7,29\%.

3. Deskripsi FDR

Variabel FDR mencapai nilai tertinggi pada bulan Agustus 2010 yakni sebesar 139,96\% dan mencapai nilai terendah pada bulan Februari 2013 yakni sebesar 119,46\%. Nilai rata-rata variabel FDR selama periode pengamatan sebesar $128,43 \%$.

4. Deskripsi OER

variabel OER mencapai nilai terendah pada bulan Desember 2009 yakni sebesar $64,69 \%$ dan mencapai nilai tertinggi pada bulan Mei 2009 yakni sebesar 91,35\%. Rata-rata nilai variabel OER selama periode pengamatan sebesar $78,08 \%$.

\section{Pengujian Asumsi Klasik}

1. Uji Normalitas

Uji normalitas bertujuan untuk menguji apakah dalam model regresi, variabel penganggu atau residual memiliki distribusi normal (Ghozali, 2013:160). Uji normalitas dapat dilakukan dengan dua cara, yaitu cara pertama adalah dengan melihat gambar P-P Plot dan apabila titik-titik menyebar mengikuti garis diagonal maka residual model regresi terdistribusi normal.

Cara kedua melakukan uji statistik dengan uji Kolmorogov-Smirnov, apabila nilai Asymp. Sig. (2-tailed) lebih besar dari $a=5 \%$ atau 0,05 , maka dapat disimpulkan bahwa residual pada model regresi mengikuti distribusi normal.
Berdasarkan gambar 2 dan tabel 1 terlihat bahwa model regresi lolos uji normalitas.

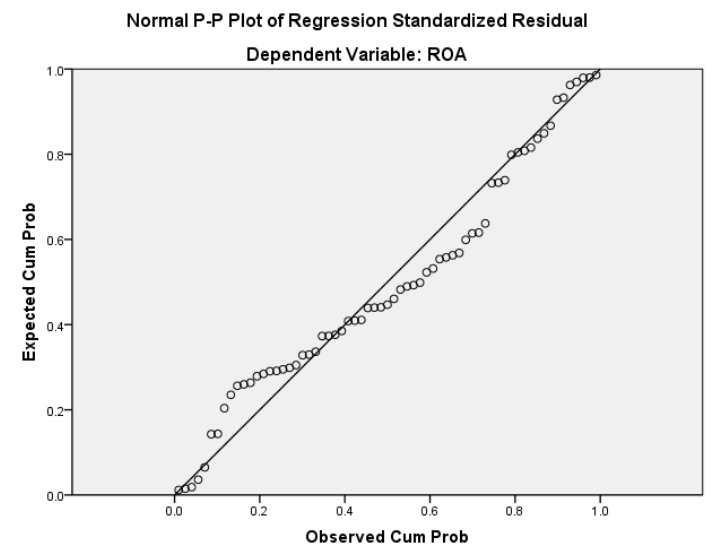

Sumber: Output PASW versi 18

Gambar 2.

Normal P-P Plo†

Tabel 1.

Uji Normalitas

\begin{tabular}{|l|c|l|}
\hline $\begin{array}{l}\text { Nilai } \\
\text { Asymp. Sig. } \\
\text { (2-tailed) }\end{array}$ & a & Kesimpulan \\
\hline 0,400 & $\begin{array}{c}5 \% \\
\text { atau } \\
0,05\end{array}$ & $\begin{array}{l}\text { Residual } \\
\text { Polar }\end{array}$ \\
& Normal & Distribusi \\
\hline
\end{tabular}

Sumber: Output PASW versi 18

2. Uji Autokorelasi

Tabel 2.

Uji Autokorelasi

\begin{tabular}{|c|c|l|}
\hline $\begin{array}{c}\text { Tabel } \\
\text { Durbin- } \\
\text { Watson } \\
\text { Dengan } \\
a=5 \%\end{array}$ & $\begin{array}{c}\text { d Hitung } \\
\text { Pada } \\
\text { Output } \\
\text { PASW }\end{array}$ & \\
\hline $\begin{array}{c}D=1,7311 \\
D I=1,4709\end{array}$ & 1,936 & $\begin{array}{l}\text { Tidak Terjadi } \\
\text { Autokorelasi }\end{array}$ \\
\hline
\end{tabular}

Sumber: Output PASW versi 18

Uji autokorelasi bertujuan untuk menguji apakah dalam model regresi linier ada korelasi antara kesalahan penganggu pada periode $\dagger$ dengan kesalahan penganggu pada periode $t-1$ (sebelumnya) (Ghozali, 2013:110). Apabila nilai d hitung lebih besar dari du tabel Durbin-Watson dan lebih kecil dari 4-du 
( $d u<d<4-d u$ ), maka dapat dikatakan model regresi yang digunakan terbebas dari masalah autokorelasi.

3. Uji Multikolinieritas

Uji multikolinieritas bertujuan untuk menguji apakah model regresi ditemukan adanya korelasi antar variabel bebas (independen) (Ghozali, 2013:105). Apabila nilai VIF masing-masing variabel independen kurang dari 10 (VIF < 10), maka model regresi terbebas dari masalah multikolinieritas.

Tabel 3.

Uji Multikolinieritas

\begin{tabular}{|l|c|c|}
\hline $\begin{array}{c}\text { Variabel } \\
\text { Bebas }\end{array}$ & $\begin{array}{c}\text { Nilai } \\
\text { VIF }\end{array}$ & Kesimpulan \\
\hline CAR & 1,930 & Bebas Multikolinieritas \\
\hline NPF & 1,445 & Bebas Multikolinieritas \\
\hline FDR & 1,112 & Bebas Multikolinieritas \\
\hline OER & 1,777 & Bebas Multikolinieritas \\
\hline
\end{tabular}

Sumber: Output PASW versi 18

4. Uji Heteroskedisitas

Uji Heteroskedisitas bertujuan untuk menguji apakah dalam model regresi terjadi ketidaksamaan variance dari residual satu pengamatan ke

\begin{tabular}{|l|c|c|}
\hline $\begin{array}{c}\text { Variabel } \\
\text { Bebas }\end{array}$ & $\begin{array}{c}\text { Nilai } \\
\text { Sig. }\end{array}$ & \multicolumn{1}{|c|}{ Kesimpulan } \\
\hline CAR & 0,266 & Bebas Heteroskedisitas \\
\hline NPF & 0,481 & Bebas Heteroskedisitas \\
\hline FDR & 0,080 & Bebas Heteroskedisitas \\
\hline OER & 0,359 & Bebas Heteroskedisitas \\
\hline
\end{tabular}
pengamatan yang lain (Ghozali, 2013:139). Uji heteroskedisitas dapat

\begin{tabular}{|l|c|c|c|c|c|}
\hline$n$ & $R^{2}$ & $d f$ & $a$ & $\begin{array}{c}c^{2} \\
\text { tabel }\end{array}$ & $\begin{array}{c}c^{2} \text { hitung } \\
=n \times R^{2}\end{array}$ \\
\hline 65 & 0,00 & 3 & 0,05 & 7,815 & 0,00 \\
\hline
\end{tabular}

dilakukan dengan dua cara. Cara pertama dengan melihat penyebaran titik-titik pada gambar scatterplot, apabila titik-titik menyebar tidak membentuk pola tertentu maka model regresi terbebas dari masalah heteroskedisitas. Cara kedua melakukan uji statistik dengan uji Glejser. Uji Glejser dilakukan dengan cara mengabsolutkan residual dan kemudian nilai absolut residual tersebut diregresikan terhadap variabel independen (CAR, NPF, FDR, dan OER). Apabila nilai signifikansi dari masing-masing variabel independen lebih besar dari $a=0,05$ maka model regresi terbebas dari masalah heteroskedisitas. Berdasarkan gambar 3 terlihat bahwa titik-titik menyebar tidak membentuk pola tertentu dan berdasarkan tabel 4 terlihat bahwa nilai signifikansi masing-masing variabel independen lebih besar dari 0,05, sehingga model terbebas dari masalah heteroskedisitas.

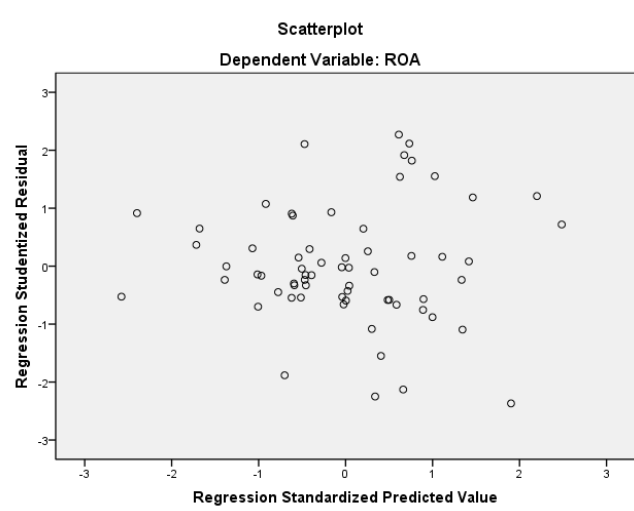

Sumber: Output PASW versi 18 Gambar 3.

Pola Scatterplot Uji Heteroskedisitas

Tabel 4.

Uji Heteroskedisitas

Sumber: Output PASW versi 18

5. Uji Linieritas

Tabel 5.

Uji Linieritas

Sumber: Output PASW versi 18

Uji ini digunakan digunakan apakah melihat apakah spesifikasi model yang digunakan sudah benar atau tidak 
(Ghozali, 2013:166). Salah satu uji linieritas yang dapat digunanakan adalah uji Lagrange Multiplier (LM).

Berdasarkan tabel 5, $c^{2}$ hitung lebih kecil dari $c^{2}$ tabel ( $c^{2}$ hitung $<c^{2}$ tabel), sehingga dapat ditarik kesimpulan bahwa model yang benar adalah model linier.

\section{Analisis Koefisien Determinasi dan Pengujian Hipotesis}

Tabel 6 menampilkan output program PASW versi 18.

Tabel 6.

Output PASW versi 18

\begin{tabular}{|c|c|c|c|}
\hline Variabel & $\begin{array}{c}\text { Koef. } \\
\text { Regresi }\end{array}$ & $\dagger$ & Sig. \\
\hline Konstanta & 3.684 & 2.173 & .034 \\
\hline CAR & -.013 & -.883 & .381 \\
\hline NPF & .083 & .964 & .339 \\
\hline FDR & .011 & 1.099 & .276 \\
\hline OER & -.031 & - & .008 \\
\hline $\begin{array}{c}\text { Koef. } \\
\text { Determinasi } \\
\text { (R2) }\end{array}$ & \multicolumn{3}{|c|}{0.75175} \\
\hline F & \multicolumn{3}{|c|}{3,171} \\
\hline Signifikansi & \multicolumn{3}{|c|}{0,020} \\
\hline Sumber: ONPS
\end{tabular}

Sumber: Output PASW versi 18

Berdasarkan tabel 6 dapat dibentuk persamaan regresi linier berganda yakni:

$$
\mathrm{ROA}=3,684-0,013 \mathrm{CAR}+0,083 \mathrm{NPF}+
$$$$
\text { 0,011FDR - 0,031 OER }
$$

Berdasarkan tabel 6 terlihat pula bahwa $R^{2}$ sebesar 0,175 atau 17,5\%, sehingga dapat disimpulkan bahwa variabel CAR, NPF, FDR, dan OER dapat menjelaskan variabel ROA sebesar $17,5 \%$, sedangkan sisanya sebesar $82,5 \%$ dijelaskan oleh variabel-variabel lain diluar model. Pengujian hipotesis untuk uji $\mathrm{F}$ dan uji † adalah sebagai berikut:

1. $p$-value uji $F$ sebesar 0,020 atau $2 \%$ dan menunjukkan bahwa $p$-value uji $F$ lebih kecil dari $a=5 \%$, sehingga variabel CAR, NPF, FDR, dan OER secara simultan berpengaruh signifikan terhadap ROA dan Hipotesis 1 diterima.

2. p-value uji $\dagger$ untuk variabel CAR, NPF, dan FDR lebih besar dari $a=5 \%$ yakni masing-masing sebesar 38,1\%, 33,9\%, dan 27,6\%, sehingga Hipotesis 2, Hipotesis 3, dan Hipotesis 4 ditolak. Kesimpulannya adalah CAR, NPF, dan FDR secara parsial berpengaruh tidak signifikan terhadap ROA. Variabel OER memiliki $p$-value sebesar $0,8 \%$ dan lebih kecil dari $a=5 \%$, sehingga OER berpengaruh signifikan terhadap ROA dan Hipotesis 5 diterima.

\section{Pembahasan}

Berdasarkan uji asumsi klasik yang dilakukan dapat disimpulkan bahwa seluruh uji asumsi klasik telah terpenuhi dan terlihat bahwa nilai $R^{2}$ pada penelitian ini sebesar $17,5 \%$, sedangkan $82,5 \%$ dipengaruhi oleh variabel lain diluar model. Variabel lain tersebut dapat berupa inflasi, LTA, NOM, dan PPAP. Adapun uji hipotesis dalam penelitian ini akan dijelaskan sebagai berikut:

1. Pengaruh CAR, NPF, FDR, dan OER Secara Simultan Terhadap ROA 
Uji simultan menyatakan bahwa CAR, NPF, FDR, dan OER secara simultan berpengaruh terhadap ROA dengan $p$ value lebih kecil dari a $(0,020<0,05)$. Hal ini menunjukkan bahwa kinerja keuangan BPRS yang diukur dengan menggunakan variabel CAR, NPF, FDR, dan OER secara simultan berpengaruh signifikan terhadap ROA. Hal ini menunjukkan bahwa setiap BPRS harus menunjukkan kinerja yang baik dengan cara memperhatikan setiap rasio keuangannya untuk mendapatkan keuntungan yang optimal.

2. Pengaruh CAR Terhadap ROA

Uji parsial menyatakan bahwa CAR berpengaruh tidak signifikan terhadap ROA yang ditunjukkan dengan p-value yang lebih besar dari a $(0,381>$ $0,05)$. CAR berpengaruh tidak signifikan terhadap ROA dapat disebabkan oleh sikap dari manajemen BPRS yang menjaga agar tingkat CAR pada BPRS tetap sesuai dengan ketetapan Bank Indonesia yaitu minimal $8 \%$ sehingga hal ini dapat menyebabkan BPRS tidak optimal dalam memanfaatkan modal yang dimiliki. Hasil penelitian ini sesuai dengan penelitian yang dilakukan oleh Sabir, dkk (2012) yang menyatakan bahwa CAR berpengaruh tidak signifikan terhadap ROA pada Bank Umum Syariah.

3. Pengaruh NPF Terhadap ROA

Uji parsial menyatakan bahwa NPF berpengaruh tidak signifikan terhadap ROA yang ditunjukkan dengan p-value yang lebih besar dari a $(0,339>0,05)$. NPF berpengaruh tidak signifikan terhadap ROA dapat disebabkan oleh pembiayaan murabahah merupakan pembiayaan yang paling banyak digunakan sedangkan pembiayaan non-lancar lebih banyak terjadi pada pembiayaan modal kerja yang menggunakan akad mudharabah. Antonio (2001:161-162) menjelaskan bahwa bank syariah dalam memenuhi kebutuhan modal kerja tidak dengan meminjamkan vang, namun menjalin hubungan partnership dengan bank syariah sebagai penyandang dana (shahibul maal) sedangkan nasabah bertindak sebagai pengelola dana (mudharib) dan skema ini lebih dikenal dengan pembiayaan mudharabah (trust financing). Ismail (2011:141) menyatakan pembiayaan murabahah kurang cocok untuk pembiayaan modal kerja yang diberikan langsung dalam bentuk uang. Hasil penelitian ini mendukung penelitian yang dilakukan oleh Purbaningsih (2014) menyatakan bahwa NPF berpengaruh tidak signifikan terhadap ROA.

4. Pengaruh FDR Terhadap ROA

Uji parsial menyatakan bahwa FDR berpengaruh tidak signifikan terhadap ROA yang ditunjukkan dengan p-value lebih besar dari a $(0,276>0,05)$. FDR berpengaruh tidak signifikan terhadap ROA dapat disebabkan oleh pembiayaan yang disalurkan oleh BPRS belum berjalan secara efektif dan optimal, sehingga menyebabkan pembiayaan non-lancar meningkat seiring dengan total pembiayaan yang disalurkan oleh BPRS. Hal ini dapat terjadi sebab pihak manajemen BPRS kurang menerapkan prinsip kehati-hatian dalam menilai calon 
nasabah pembiayaan. Hasil penelitian ini mendukung penelitian Purbaningsih (2014) yang menyatakan FDR berpengaruh tidak signifikan terhadap ROA.

5. Pengaruh OER Terhadap ROA

Uji parsial menyatakan bahwa OER berpengaruh signifikan terhadap ROA yang ditunjukkan dengan $p$-value lebih kecil dari a $(0,008<0,05)$. OER berpengaruh signifikan terhadap ROA dapat disebabkan oleh rata-rata OER selama periode pengamatan sebesar $78,08 \%$ dan nilai rata-rata OER masih dibawah ketetapan nilai maksimal OER BPRS seperti yang tercantum dalam Surat Edaran Bank Indonesia Nomor 9/29/DPbs tanggal 7 Desember 2007 yakni 87\%. Dengan nilai rata-rata yang masih dibawah ketentuan dari Bank Indonesia maka dapat disimpulkan secara industri, BPRS sudah mencapai efisiensi operasi yang baik dan stabil sehingga memiliki potensi yang tinggi dalam memperoleh keuntungan. Hasil penelitian ini mendukung penelitian yang dilakukan oleh Sukarno dan Syaichu (2006) yang menyatakan bahwa BOPO berpengaruh signifikan terhadap ROA.

\section{SIMPULAN}

Berdasarkan hasil dan pembahasan yang telah dikemukakan sebelumnya, maka simpulan yang dapat diambil dari penelitian ini adalah:

1. Capital Adequacy Ratio (CAR), Non Performing Financing (NPF), Financing to Deposit Ratio (FDR), dan Operational Efficiency Ratio (OER) secara simultan berpengaruh terhadap Return on Assets (ROA) pada BPRS di Indonesia.

2. Capital Adequacy Ratio (CAR), Non Performing Financing (NPF), dan Financing to Deposit Ratio (FDR) secara parsial bepengaruh tidak signifikan terhadap Return on Assets (ROA) pada BPRS di Indonesia.

3. Operational Efficiency Ratio (OER) secara parsial berpengaruh signifikan terhadap Return on Assets (ROA) pada BPRS di Indonesia.

Saran yang dapat diberikan berdasarkan penelitian ini adalah:

1. Bagi Bank Pembiayaan Rakyat Syariah BPRS terus memantau kinerja keuangannya terlebih lagi rasio OER, sebab rasio OER merupakan satusatunya rasio yang berpengaruh signifikan terhadap ROA, sehingga BPRS diharapkan terus meningkatkan efisiensi operasionalnya agar dapat meningkatkan keuntungan. Pihak BPRS juga perlu memperhatikan rasio-rasio lainnya seperti CAR, NPF, dan FDR.

2. Bagi Otoritas Jasa Keuangan (OJK) OJK selaku regulator harus selalu memantau setiap kinerja BPRS diseluruh Indonesia dan secara cepat memberikan evaluasi kepada BPRS yang dirasa tidak berjalan lancar

3. Bagi Penelitian Selanjutnya

Diharapkan meneliti dengan
menggunakan variabel yang
berbeda.
berbeda. 


\section{DAFTAR PUSTAKA}

Almilia, Luciana Spica \& Winny Herdiningtyas. 2005. Analisis Rasio CAMEL Terhadap Prediksi Kondisi Bermasalah Pada Lembaga Perbankan Perioda 2000-2002. Jurnal Akuntansi dan Keuangan, (Online), Vol. 7, No. 2, (www.spicaamalia.files.wordpress.co m, diakses 21 September 2014)

Anshori, Muslich \& Sri Iswati. 2009. Buku Ajar Metodologi Penelitian Kuantitatif. Surabaya: Airlangga University Press

Antonio, Muhammad Syafi'i. 2001. Bank Syariah Dari Teori Ke Praktik. Jakarta: Gema Insani

Arifin, Zainul. 2009. Dasar-Dasar Manajemen Bank Syariah. Jakarta: Azkia Publisher

Dendawijaya, Lukman. 2003. Manajemen Perbankan. Jakarta: Ghalia Indonesia

Departemen Agama RI. 2004. Mushaf Al-Qur'an dan Terjemahnya Revisi Tahun 2004. Jakarta: DEPAG RI

Ghozali, Imam. 2013. Aplikasi Analisis Multivariate dengan Program IBM SPSS 21 Update PLS Regresi. Semarang: Badan Penerbit Universitas Diponegoro

Gitman, Lawrence J \& Chad J. Zutter. 2012. Principles of Managerial Finance. Thirteenth Edition. England: Pearson Education Hutagalung, Esther Novelina dkk. 2013. Analisis Rasio Kevangan Terhadap Kinerja Bank Umum di Indonesia.
Jurnal Aplikasi Manajemen, (Online),

Vol. 11, No. 1, (www.jurnaljam.ub.ac.id, diakses 21 September 2014)

Ismail. 2011. Perbankan Syariah. Jakarta: Kencana

Muhammad. 2004. Manajemen Dana Bank Syariah. Yogyakarta: Ekonisia Pratiwi, Dhian Dayinta. 2012. Pengaruh CAR, BOPO, NPF, dan FDR Terhadap Return on Assets (ROA) Bank Umum Syariah (Studi Kasus pada Bank Umum Syariah di Indonesia Tahun 2005-2010). Skripsi S-1 Fakultas Ekonomika dan Bisnis Universitas Diponegoro, (Online), (www.eprints.undip.ac.id, diakses 17 September 2014)

Purbaningsih, Yoppy Palupi. 2014. The Effect of Liquidity Risk and Non Performing Financing (NPF) Ratio to Commercial Sharia Bank Profitability in Indonesia. International Proceedings of Economics Development and Research, (Online), Vol. 73, 12, (www.search.proquest.com, diakses 6 November 2014)

Republik Indonesia. Outlook Perbankan Syariah 2013. 2012, (Online), (ekonomisyariah.info, diakses 4 September 2014)

Statistik Perbankan Syariah, Januari 2009-Mei 2014. 20092014, (Online), (www.ojk.go.id, diakses 2 September 2014) - Surat Edaran Bank Indonesia Nomor 9/29/DPbs Tahun 
2007 Tentang Sistem Penilaian Tingkat Kesehatan Bank Pengkreditan Rakyat Berdasarkan Prinsip Syariah. 2007, (Online), (www.bi.go.id, diakses 21 September 2014) Undang-Undang

Nomor 21 Tahun 2008 Tentang Perbankan Syariah. 2008, (Online), (www.ojk.go.id, diakses 20 September 2014)

Rivai, Veithzal dan Arifin. 2010. Islamic Banking Sebuah Teori, Konsep, dan Aplikasi. Jakarta: Bumi Aksara

Sabir. M, Muh dkk. 2012. Pengaruh Rasio Kesehatan Bank Terhadap Kinerja Keuangan Bank Umu Syariah dan Bank Konvensional di Indonesia. Jurnal Analisis, (Online), Vol. 1, No. 1:79-86, (www.pasca .unhas.ac.id, diakses 21 September 2014)

Sukarno, Kartika Wahyu \& Muhamad Syaichu. 2006. Analisis Faktor-Faktor yang Mempengaruhi Mempengaruhi Kinerja Bank Umum di Indonesia. Jurnal Studi Manajemen \& Organisasi, (Online), Vol. 3, No. 2, (www.ejournal.undip.ac.id/index.ph p/smo, diakses 21 September 2014) Suryani. 2011. Analisis Pengaruh Financing to Deposit Ratio (FDR) Terhadap Profitabilitas Perbankan Syariah di Indonesia, (Online), Vol. 19. No. 1:47-74, (www.journal.walisongo.ac.id, diakses 13 Januari 2015)
Wibowo. 2011. Manajemen Kinerja. Jakarta: PT. Rajagrafindo Persada Widati, Listyorini Wahyu. 2012. Analisis Pengaruh CAMEL Terhadap Kinerja Perusahaan Perbankan yang Go Public. Dinamika Akuntansi, Keuangan dan Perbankan, (Online), Vol. 1, No. 2: 105-119, (download.portalgaruda.org, diakses 26 September 2014 